\title{
Oxidative Stress Effects of Soluble Sulfide on Human Hepatocyte Cell Line LO2
}

\author{
Ying Shao ${ }^{1}$, Zhongli Chen ${ }^{2, *}$ and Lingling $\mathrm{Wu}^{3, *}$ \\ 1 Institute for Environmental Research (Bio V), RWTH Aachen University, Worringerweg 1, \\ 52074 Aachen, Germany; ying.shao0926@outlook.com \\ 2 Key Laboratory of the Three Gorges Reservoir Eco-environment, Ministry of Education, \\ Chongqing University, Chongqing 400045, China \\ 3 Key Laboratory of Yangtze River Water Environment, Ministry of Education, Tongji University, \\ Shanghai 200092, China \\ * Correspondence: zhongli.chen@cqu.edu.cn (Z.C.); wulingling@tongji.edu.cn (L.W.); \\ Tel.: +86-23-65120750 (Z.C.); +86-21-65988598 (L.W.)
}

Received: 1 April 2019; Accepted: 10 May 2019; Published: 13 May 2019

\begin{abstract}
Soluble sulfide is well known for its toxicity and corrosion for hundreds of years. However, recent studies have demonstrated that hydrogen sulfide $\left(\mathrm{H}_{2} \mathrm{~S}\right)$ - a novel gasotransmitter-supports a critical role during neuromodulation, cell proliferation, and cardioprotection for organisms. In particular, soluble sulfide plays multifaceted signaling functions in mammals during oxidative stress processes. However, the specific molecular regulation of soluble sulfide during oxidative stress remains unclear. In this study, $\mathrm{Na}_{2} \mathrm{~S}$ was implemented as a soluble sulfide donor to expose LO2 cells. The 3-(4,5-dimethylthiazolyl-2),-2,5-diphenyltetrazolium bromide (MTT) assay, hydroxyl radical assay, superoxide dismutase (SOD) assay, and glutathione peroxidase (GSH-PX) assay were applied to analyze cytotoxicity, hydroxyl radical levels, SOD and GSH-Px activities, respectively. Soluble sulfide at a concentration $0.01-1.0 \mathrm{mM} / \mathrm{L}$ resulted in a marked and concentration-dependent reduction of $\mathrm{LO} 2$ cell viability. At low concentrations, sulfide solutions increased SOD activity and GSH-Px activity of LO2 after $24 \mathrm{~h}$ exposure, exhibiting a clear hormesis-effect and indicating the protective ability of soluble sulfide against oxidative stress. The decline in SOD and GSH-Px and the increase in hydroxyl radical $(0.08-1.0 \mathrm{mM} / \mathrm{L})$ suggested that oxidative damage could be a possible mechanism for sulfide-induced cytotoxicity.
\end{abstract}

Keywords: soluble sulfide; oxidative stress; cytotoxicity; superoxide dismutase (SOD) activity; glutathione peroxidase (GSH-Px) activity

\section{Introduction}

Sulfide, as an inorganic anion of sulfur, is found in concentrations ranging from $\mu \mathrm{g} / \mathrm{L}$ to $\mathrm{mg} / \mathrm{L}$ in the surface water [1], sewers [2], waste water, waste water treatment plants [3], and biological fluid such as rat blood [4]. In the aquatic environment, soluble sulfide which has been known for its toxicity and corrosion for hundreds of years normally coexists as sulfide ion $\left(\mathrm{S}^{2-}\right)$, hydrosulfide $\left(\mathrm{HS}^{-}\right)$and hydrogen sulfide $\left(\mathrm{H}_{2} \mathrm{~S}\right)$ [3]. In particular $\mathrm{H}_{2} \mathrm{~S}$, one of the most toxic chemicals in the end of Permian period, is recognized as the root cause for multiple mass extinctions on earth [5]. Moreover, dissolved free sulfides by means of $\mathrm{H}_{2} \mathrm{~S}, \mathrm{HS}^{-}$, and $\mathrm{S}^{2-}$ cause strong aggressive corrosion of many metals, which is a major process affecting sewer systems, leading to very high maintenance costs worldwide [6].

Recent studies have illustrated that $\mathrm{H}_{2} \mathrm{~S}$ has emerged as a novel gaseous signaling molecule (gasotransmitter), which is as important as nitric oxide (NO), carbon monoxide (CO), and hydrogen peroxide $\left(\mathrm{H}_{2} \mathrm{O}_{2}\right)[7,8]$ for animals and plants. $\mathrm{H}_{2} \mathrm{~S}$, as a physiologic mediator, is found to participate 
in many physiological and pathological processes in various organisms. It has been identified in cardiovascular, immune, and nervous systems during apoptosis [9]; during inflammatory processes, protective effects against hypoxia, neuromodulation, cell proliferation and cardioprotection $[8,10]$. Therefore, public concerns were received regarding $\mathrm{H}_{2} \mathrm{~S}$ worldwide [11]. In 2011, an European network on gasotransmitters (ENOG) was formed to promote research on $\mathrm{H}_{2} \mathrm{~S}$, aiming to unravel its roles in human health and disease [12], and achieved many results. For instance, $\mathrm{H}_{2} \mathrm{~S}$ is involved in smooth muscle relaxation that causes penile erection, thus presenting possible new therapeutic opportunities for erectile dysfunction [13]. $\mathrm{H}_{2} \mathrm{~S}$, as a smooth muscle relaxant, can relax blood vessels via activating ATP-sensitive potassium channels in smooth muscle cells [14]. Exogenous $\mathrm{H}_{2} \mathrm{~S}$ induces the decline in blood pressure and the progression of nephropathy in mammals [15]. $\mathrm{H}_{2} \mathrm{~S}$ serves as a component of vasodilators that is potentially protecting against cardiovascular disease [11]. $\mathrm{H}_{2} \mathrm{~S}$ stimulates the increased response of $\mathrm{N}$-methyl-D-aspartate receptors and facilitates long-term potentiation, which may influence memory formation [16]. NaHS at environmental concentrations of 30-50 $\mu \mathrm{mol} / \mathrm{L}$ could reduce the homocysteine-induced cytotoxicity in vascular smooth muscle cells [17]. It is noticeable, however, that soluble sulfide, as a reducing substance, plays an important role during oxidative stress regulation within organisms. A cystathionine gamma-lyase study reported that $\mathrm{H}_{2} \mathrm{~S}$ reduction may contribute to cisplatin-induced renal cell injury, which is possibly caused by the augmentation of endogenous reactive oxygen species (ROS) production. NaHS pretreated $\mathrm{PCl}_{2}$ cells have been found to inhibit ROS production through cobalt chloride $\left(\mathrm{CoCl}_{2}\right)$ [18]. Hydrogen sulfide protects the integrity of the blood-brain barrier following cerebral ischemia possibly by inhibiting free radical production [19]. Even though the protective effects of low dose $\mathrm{H}_{2} \mathrm{~S}$ on neurons and cardiac muscles against oxidative stress have been frequently observed in many studies [20,21], a data gap remains with regard to the specific regulation mechanism of soluble sulfide during oxidative stress in human hepatocyte cells. Thus, the research questions guiding this study were: 1) how can soluble sulfide regulate oxidative stress in human hepatocytes? 2) Does soluble sulfide have any antioxidant capacity? If yes, 3) at what concentration does soluble sulfide induce antioxidantion? Considering the toxicity of soluble sulfide, is there any linkage between oxidative stress and cytotoxicity at high doses of soluble sulfide exposure?

To answer the above questions, we used the human hepatocyte cell line LO2 was used to test the cytotoxicity and the regulatory effects of soluble sulfide. The LO2 cells have been reported to be an ideal alternative to in vivo tests with intact hepatocyte enzyme activities, which closely resemble the enzyme activity levels of the current population [22]. $\mathrm{Na}_{2} \mathrm{~S}$, a soluble sulfide donor [3,23], was used to expose LO2 cells to different concentrations. We also used the 3-(4,5-dimethylthiazolyl-2),-2,5-diphenyltetrazolium bromide (MTT) assay, an important in vitro method for toxicological analysis [24], to assess the cytotoxic potential of soluble sulfide. This assay determines cell viability in terms of reductive activity by measuring the enzymatic conversion of tetrazolium compounds to water-insoluble formazan crystals by dehydrogenases found in the mitochondria of living cells [25]. Oxidative stress reflects the imbalance between the systemic manifestation of reactive oxygen species (ROS) including peroxides, superoxide, hydroxyl radical, singlet oxygen, and alpha-oxygen [26]. Toxic effects could be induced by disturbing the cells' normal redox state through the production of peroxides and free radicals, leading to damage in the whole cell components, including proteins, lipids, and DNA [27]. To analyze the specific regulatory effects of soluble sulfide on oxidative stress, ROS including hydroxyl radical, superoxide and peroxides were detected by the hydroxyl radical assay, superoxide dismutase (SOD) assay, and the glutathione peroxidase (GSH-PX) assay after $24 \mathrm{~h}$ of exposure, respectively [28,29]. These oxidative stress tests and cytotoxicity assay were performed at different sulfide concentrations to explore the specific mechanism of sulfide induced oxidative damage. 


\section{Materials and Methods}

\subsection{Materials}

$\mathrm{Na}_{2} \mathrm{~S} \cdot 9 \mathrm{H}_{2} \mathrm{O}(98 \%)$ was purchased from Shanghai TongYa Chemical Industry Science and Technology Co. Ltd. The $\mathrm{NaOH}$ and $\mathrm{HCl}$ used to adjust $\mathrm{pH}$ values were obtained from Sinopharm Chemical Reagents Co. Ltd (Shanghai, PR China). In this study, we used double-distilled water passed through a reverse osmosis system and further treated with a Hitech-K flow water purification system.

Dulbecco's modified Eagle's medium (DMEM), fetal bovine serum (FBS), and 0.25\% trypsin were purchased from KeyGen BioTECH. Co. Ltd. 3-(4,5-Dimethylthiazol-2-yl)-2,5-diphenyl tetrazolium bromide (MTT) was provided by the Nanjing Jiancheng Bioengineering Institute. Antibiotic-antimycotic and DMSO were produced by the Institute of Nanjing Jiancheng Biology Engineering (Nanjing, PR China). Bovine serum was provided by Hangzhou Sijiqing Biological Engineering Co. Ltd. (Hangzhou, PR China). All other chemicals were purchased from Nanjing Ronghua Reagent Co. (Nanjing, PR China).

\subsection{Cell Culture}

The human normal hepatocyte LO2 cells were purchased from KeyGen BioTECH. Co. Ltd. (Nanjing, PR China). Cell culture was conducted according to the method described by Tang et al. [30], with slight modifications. The cells were grown in Dulbecco's modified Eagle's medium (DMEM) supplemented with $10 \%(\mathrm{v} / \mathrm{v})$ fetal bovine serum (FBS) and $1 \%$ antibiotic-antimycotic, in polystyrene flasks $\left(75 \mathrm{~cm}^{2}\right.$, Corning Incorporated) at $37{ }^{\circ} \mathrm{C}$ in $5 \% \mathrm{CO}_{2}$. The media was changed every 2 days. $\mathrm{LO} 2$ cells were maintained in growth phase by splitting every 3 days using $0.25 \%(\mathrm{v} / \mathrm{v})$ trypsin-ethylene diamine tetraacetic acid (EDTA, $1 \mathrm{mM}$ ).

\subsection{The MTT Assay}

Cytotoxicity of soluble sulfide in LO2 cells was tested using the MTT assay. The MTT assay was conducted according to the protocol described by Storch et al. [31], with slight modifications. LO2 cells were cultured in DMEM (Gibco, Thermo Fisher, Germany) in 96-well plates at 10,000 cells/well density, and were incubated for $24 \mathrm{~h}$ at $37^{\circ} \mathrm{C}$ in $5 \% \mathrm{CO}_{2}$. The cells were then exposed to soluble sulfide solutions at concentrations of $0.01,0.05,0.1,0.2,0.5$, and $1.0 \mathrm{mM} / \mathrm{L}$ at $37^{\circ} \mathrm{C}$ for $24 \mathrm{~h}$. After incubation, $100 \mu \mathrm{L}$ of MTT ( $0.5 \mathrm{~g} / \mathrm{L}$ with reagent in D-MEM medium) was added to each well and the cells were incubated for $30 \mathrm{~min}$ at $37^{\circ} \mathrm{C}$. The MTT solution was then removed, $200 \mu \mathrm{L}$ of DMSO was added, and the plates were incubated for $15 \mathrm{~min}$ at $37^{\circ} \mathrm{C}$ to dissolve the formazan crystals. Finally, the absorbance of each well was immediately measured on an ELISA micro-plate reader (BIO-RAD, USA) at $550 \mathrm{~nm}$ to determine cellular viability.

\subsection{Measurement of the Hydroxyl Radical}

Hydroxyl radicals were generated by a Fenton reaction $\left(\mathrm{Fe}^{3+}\right.$-ascorbate-EDTA- $\mathrm{H}_{2} \mathrm{O}_{2}$ system), and the scavenging capacity towards hydroxyl radicals was measured using a deoxyribose method previously described by Szabo et al. [32] with slight modifications. Reaction mixtures consisted of $1.0 \mathrm{mM} / \mathrm{L}$ deoxyribose, $1.0 \mathrm{mM} / \mathrm{L} \mathrm{H}_{2} \mathrm{O}_{2}, 1.0 \mathrm{mM}$ ascorbate, and $1.0 \mathrm{mg} / \mathrm{ml}$ of particles in a total volume of $2 \mathrm{ml}$. In control samples, the mixtures were replaced by PBS. The mixtures were incubated at $37^{\circ} \mathrm{C}$ for $1.5 \mathrm{~h}$ with agitation and then centrifuged at $1200 \times \mathrm{g}$ for $10 \mathrm{~min}$. TBA $(1 \mathrm{ml} ; 1 \% \mathrm{w} / \mathrm{v})$ and trichloroacetic acid $(2.8 \%, \mathrm{w} / \mathrm{v})$ were added to each of the supernatants $(1 \mathrm{ml})$, followed by heating at $37^{\circ} \mathrm{C}$ for $3 \mathrm{~min}$ [33]. The reaction produced a pink chromogen and was quantified by measuring absorbance at $530 \mathrm{~nm}$. 


\subsection{Measurement of SOD Activity}

The method of determining SOD activity has been previously described [34]. Briefly, superoxide radicals are generated by the xanthine and xanthine oxidase reaction. The amount of superoxide radical produced is measured by 2-(4-iodophenyl)-3-(4-nitrophenol)-5-phenyl tetrasodium chloride [35], which reacts with a superoxide radical to form a red formazan dye. SOD activity is then determined by the grade of the reaction's inhibition by measuring its absorbance at $550 \mathrm{~nm}$. The standard calibration curve of inhibition percentage by standard solutions and concentrations $(\mathrm{U} / \mathrm{mL})$ was used to evaluate total SOD activity.

\subsection{Measurement of GSH-Px Activity}

GSH-Px activity was measured indirectly by measuring the rate of oxidized glutation (GSSG) formation [36]. The principle of the method was as follows: GSH-Px catalyzes the oxidation of GSH with synthetic cumen hydroperoxide to GSSG. In the presence of glutathione reductase and NADPH, GSSG is immediately converted to the reduced form with a concomitant oxidation of NADPH to $\mathrm{NADP}^{+}$. The rate of NADPH oxidation was measured at absorbance $412 \mathrm{~nm}$ and is proportional to the activity of GSH-Px.

\subsection{Statistical Analysis}

All spreadsheet calculations were performed using Microsoft Excel ${ }^{\mathrm{TM}}$ 2007, Sigma Plot 12.0 (Systat Software Inc., San Jose, CA), Origin Pro 8.5.1(Origin Lab Corporation, Northampton, MA, USA) or the software Prism 6.0 (GraphPad Software Inc., San Diego, CA, USA). All datasets of different treatments were tested for statistically significant differences using one-way analysis of variance. Dunnett's test was used to identify significant differences between treatments and controls.

\section{Results}

\subsection{Cytotoxic Effects of Soluble Sulfide}

Cytotoxicity of sulfide was investigated in human hepatocyte LO2 cells using the MTT assay. Incubation of LO2 cells with sulfide solution at concentrations ranging from 0.01 to $1.0 \mathrm{mM} / \mathrm{L}$ resulted in a marked and concentration-dependent reduction in their viability (Figure 1). No cytotoxicity effect was found at $0.01 \mathrm{mM} / \mathrm{L}$, while the strongest cytotoxicity effect was recorded at $1.0 \mathrm{mM} / \mathrm{L}$, with the average survival rate accounting for $17.5 \%$.

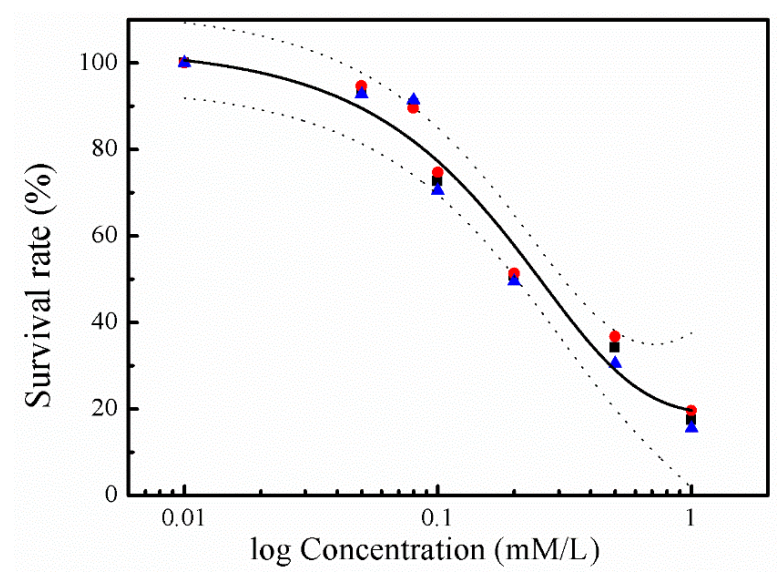

Figure 1. Concentration-response curves for the cytotoxicity of sulphide solution. The experimental data depicts viability of hepatocyte LO2 cells exposed to sulphide solutions after $24 \mathrm{~h}$ of incubation (1st replicate: red roundness; 2nd replicate: blue triangle; and 3rd: black square). The regression curves (black lines) are shown with their $95 \%$ confidence intervals (dashed lines), in which the top and bottom of the curve was set to $0 \%$ and $100 \%$, respectively. 


\subsection{Oxidative Stress Effects of Soluble Sulfide}

\subsubsection{Hydroxyl Radical Production by Soluble Sulfide}

Significant decrease in intracellular hydroxyl radical formation was found in human hepatocytes LO2 after $24 \mathrm{~h}$ of exposure at $0.01-0.1 \mathrm{mM} / \mathrm{L}$ sulfide solutions (Figure 2). The significant decline in hydroxyl radicals in the treated hepatocytes after exposure to $0.01 \mathrm{mM} / \mathrm{L}$ sulfide solution was nearly one fifth that of the control. This provided evidence of hydroxyl radical inhibition in LO2 cells after exposure to soluble sulfide, and the protective effects of soluble sulfide against oxidative stress. While LO2 exhibited virtually equal hydroxyl radical levels when exposed to a $0.1 \mathrm{mM} / \mathrm{L}$ sulfide solution, and even significantly higher hydroxyl radical levels after treatment with higher concentrations of sulfide solution, i.e., $0.1-1.0 \mathrm{mM} / \mathrm{L}$.

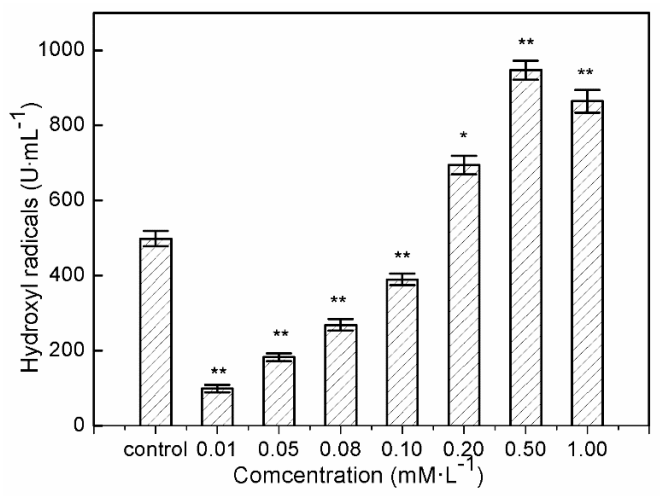

Figure 2. Hydroxyl radical generation by human hepatocytes LO2 after $24 \mathrm{~h}$ of exposure to sulfide solution. The values were determined by the Fenton reaction using a deoxyribose method. Data are given as means of three replicates $\pm \mathrm{SD}$. ${ }^{*} p<0.05,{ }^{* *} p<0.01$ : significant differences from controls.

\subsubsection{SOD and GSH-Px Activities Induction by Soluble Sulfide}

The results of SOD activity and GSH-Px activity showed similar trends. After treatment with sulfide solution at concentrations of 0.01 and $0.05 \mathrm{mM} / \mathrm{L}$ for $24 \mathrm{~h}$, SOD activity in LO2 cells increased slightly from $109.43 \pm 12.6 \mathrm{U} / \mathrm{mL}$ to $115.54 \pm 10.3 \mathrm{U} / \mathrm{mL}$, compared to the control $(102.14 \pm 13.7 \mathrm{U} / \mathrm{mL})$ (Figure 3). SOD activity then declined continuously from $92.06 \pm 12.9 \mathrm{U} / \mathrm{mL}$ to $34.42 \pm 10.4 \mathrm{U} / \mathrm{mL}$, under exposures to $0.08-1.0 \mathrm{mM} / \mathrm{L}$. GSH-Px activity increased from $85.72 \pm 21.02 \mathrm{U} / \mathrm{mL}$ to $97.47 \pm 20.72 \mathrm{U} / \mathrm{mL}$ after 0.01 and $0.05 \mathrm{mM} / \mathrm{L}$ sulfide exposure for $24 \mathrm{~h}$, and that for the treatments of $0.08-1.0 \mathrm{mM} / \mathrm{L}$ declined significantly from $64.26 \pm 22.76 \mathrm{U} / \mathrm{mL}$ to $7.22 \pm 2.35 \mathrm{U} / \mathrm{mL}$ (Figure 4).

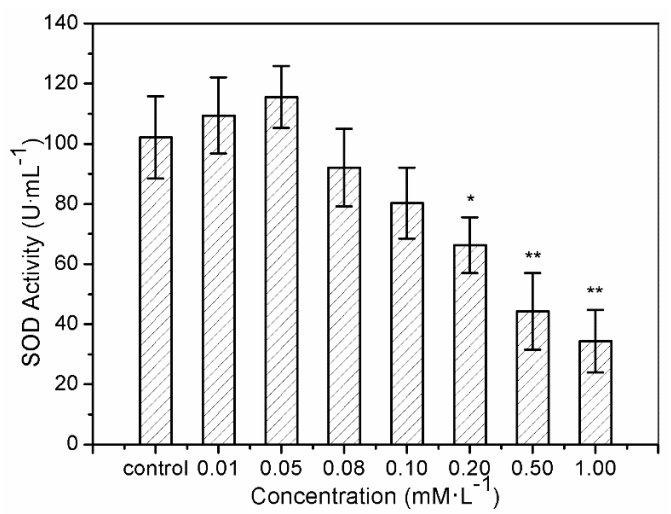

Figure 3. Superoxide dismutase (SOD) activity of the human hepatocytes LO2 after $24 \mathrm{~h}$ of exposure to sulfide solutions. The values were determined by the xanthine and xanthine oxidase reaction using 2-(4-iodophenyl)-3-(4-nitrophenol)-5-phenyl tetrasodium chloride [34]. Data are given as means of three replicates \pm SD. ${ }^{*} p<0.05,{ }^{* *} p<0.01$ : significant differences from controls. 


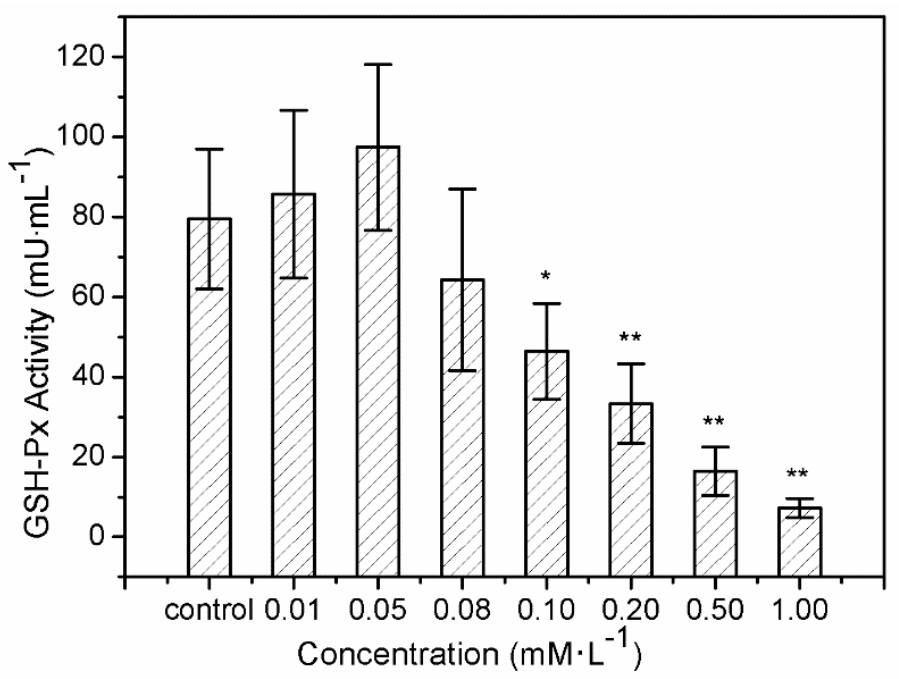

Figure 4. Glutathione peroxidase (GSH-Px) activity of the human hepatocytes LO2 after $24 \mathrm{~h}$ of exposure to sulfide solutions. The values were determined by measuring the rate of formation of oxidized glutation (GSSG). Data are given as means of three replicates \pm SD. ${ }^{*} p<0.05,{ }^{* *} p<0.01$ : significant differences from controls.

\section{Discussion}

Soluble sulfide reduces cell viability to a considerable extent only at concentrations above $0.1 \mathrm{mM} / \mathrm{L}$. Co-incubation with sulfide at $1.0 \mathrm{mM} / \mathrm{L}$ induced almost $90 \%$ viability loss for hepatocytes in the current study (Figure 1), which is in agreement with an erythrocytes study, where almost no cell remained viable after sulfide exposure at $1.5 \mathrm{mM} / \mathrm{L}$ [37]. Even though the specific toxic mechanism of sulfide in LO2 cells is still unclear, studies have revealed that the molecular mechanisms underlying the toxicological effects of $\mathrm{H}_{2} \mathrm{~S}$ are mostly attributed to mitochondrial poisoning [38,39]. Treating $\mathrm{H}_{2} \mathrm{~S}$ poisoning may benefit from interventions minimizing ROS-induced damage and reducing mitochondrial damage $[40,41]$. A NaHS study has shown that sulfide solutions have complex effects on the electrophysiological properties of neuronal membranes, and an array of $\mathrm{K}^{+}$conductance at toxicologically relevant concentrations [42]. Furthermore, the concentration-response curve of LO2 cells viability in the current study (Figure 1) indicates a gradual appearance of toxicity with the increase in sulfide concentration. These cytotoxic effects are consistent with an erythrocytes study, in which the fraction of viable cells was decreased with the increase of sulfide concentration ranging from 0.18 to $4.8 \mathrm{mM} / \mathrm{L}$ [37]. These results indicate that normal human hepatocyte $\mathrm{LO} 2$ cells show similar toxicity to erythrocytes. Thus, the environment and health risk assessment and management should pay more attention to the toxic effects when investigating soluble sulfide exposure in different tissues or cells, especially for the occupational exposure for individuals such as miners [43].

As described in a study by Turrens [44], high levels of ROS induced detrimental effects by damaging cell structures, lipids, DNA, and proteins which ultimately lead to cell death, but low "physiological" levels of ROS play important roles in signal transduction and are involved in the communication between nucleus and mitochondria $[45,46]$. ROS are reduced derivatives of molecular oxygen (e.g., $\mathrm{O}^{2-}$., $\mathrm{H}_{2} \mathrm{O}_{2}, \mathrm{OH}$, ferryl, peroxyl, and alkoxyl), being produced during energy metabolism or the defense process against infection in cells and tissues [47]. Of all generated ROS in biological systems, the hydroxyl radical is the most reactive oxygen radical. When the hydroxyl radical is generated in excess, or the cellular antioxidant defense is deficient, oxidative stress and oxidative damage to lipid, DNA, protein, and other key molecules are caused via stimulating free radical chain reactions with proteins, lipids, and nucleic acids [48]. Evidence of hydroxyl radical decline at sulfide solution concentrations of $0.01-0.1 \mathrm{mM} / \mathrm{L}$ on LO2 cells suggested possible mechanisms of anti-oxidative stress which were induced by sulfide solutions in the present study, which could help during the process of drug development to treat or relieve oxidative damage-induced disease. 
The superoxide anion $\left(\mathrm{O}^{2-}\right)$, as the first free radical of ROS generated in vivo, can initiate a variety of oxidative damage responses to phospholipids, proteins, and nucleic acids by generating many kinds of oxygen free radicals, causing degenerative diseases and aging [35,49]. SOD, an $\mathrm{O}^{2-}$ level downregulation catalyzing enzyme, is necessary for almost all organisms living in the presence of oxygen [26]. Therefore, SOD activity is often used to detect $\mathrm{O}^{2-}$ defense in cells based on the superoxide reacts. The phenomena of increase of SOD activity after $24 \mathrm{~h}$ of exposure to sulfide solutions at 0.01 and $0.05 \mathrm{mM} / \mathrm{L}$ in the current study indicates the protective function of soluble sulfide against oxidative stress, which gives further evidence of the medicinal value of low dose soluble sulfide. These results are consistent with a cardiomyocytes study, in which hydrogen sulfide decreased the levels of ROS by inhibiting mitochondrial complex IV and increasing SOD activities under ischemia/reperfusion [50]. While the study from $\mathrm{H}_{2} \mathrm{~S}$ metabolism reported that $\mathrm{H}_{2} \mathrm{~S}$ (or $\mathrm{H}_{2} \mathrm{~S}$ donors) may interact/react with SOD cysteines to affect catalytic activity or directly contribute to sulfide metabolism [51], which differs from the well-known SOD-mediated dismutation of two $\mathrm{O}^{2-}$ to form $\mathrm{H}_{2} \mathrm{O}_{2}$ and $\mathrm{O}_{2}$.

$\mathrm{H}_{2} \mathrm{O}_{2}$, as the second free radical of ROS generated in vivo, must be eliminated by the GSH-Px in the current study. GSH-Px can change lipid hydroperoxides and free hydrogen peroxide into their corresponding alcohols and water, thus protecting the organism from oxidative damage [52]. GSH-Px is hence widely used as another enzyme for detecting oxidative stress defense. The increase in GSH-Px activity provided further evidence of soluble sulfide function against oxidative stress. Moreover, recent studies provide experimental evidence of the role of antioxidant enzymes such as GSTP1 in many tissues, functioning as regulator of pro/anti apoptotic pathways [53-55]. Hydrogen sulfide regulates oxidative stress by GSH-Px through Sirtuin-1 pathway to protect against apoptosis, which was also shown in the context of cardiomyocytes [56]. The decline of GSH-Px activity at sulfide concentrations of $0.08-1.0 \mathrm{mM} / \mathrm{L}$ could be explain that the increase in ROS may be the reason for the inhibition of GSH-Px activity [57].

The present study shows that sulfide solutions at concentrations of $0.08-1.0 \mathrm{mM} / \mathrm{L}$ decreased SOD and GSH-Px activities after $24 \mathrm{~h}$ exposure, and simultaneously decreased LO2 cell viability (Figures 1, 3 and 4). This decline in SOD, GSH-Px, and cell survival rate suggests that oxidative damage could be a possible mechanism of cytotoxicity induced by soluble sulfide in LO2 cells. A necrosis study also reported that disturbed SOD could induce reverse cytoprotective properties, destabilizing the mitochondrial membrane system and promoting cell death [32]. Hydroxyl radical levels also increased at these concentration ranges in the current study (Figure 2), which gives further evidence of the oxidative damage at high concentrations of soluble sulfide on LO2 cells. Previous studies also provide experimental evidence that oxidative stress-mediated apoptosis could be activated by caspase-3, and an imbalance between Bax and Bcl-2 expression with different level bioassays [58]. Moreover, NaHS has been shown to have anti-apoptotic and anti-inflammatory signaling potential via mechanisms involving Nrf-2 by direct and indirect anti-oxidant activities [59]. While on the contrary, sulfide solutions at concentrations of 0.01 and $0.05 \mathrm{mM} / \mathrm{L}$ induced the increase of SOD and GSH-Px activities, and decrease in the hydroxyl radical level on LO2 cells (Figures 2-4). Recent studies reported that $\mathrm{H}_{2} \mathrm{~S}$ can protect neurons from oxidative stress by restoring glutathione levels for the hypochlorous acid-mediated oxidative damage in the brain [21],t renal cell carcinoma, transitional cell carcinoma in the kidneys, and urinary bladder tumors [54]. Chemicals at low concentrations exhibit protective effects by upregulating cellular antioxidant enzymes such as SOD, GSH-Px, and CAT, which has been confirmed recently with qPCR assays [60], western blot analysis, and immunofluorescence assays [61]. A biphasic response of low concentration stimulation, high concentration inhibition for SOD activity and GSH-Px activity and low concentration inhibition, high concentration stimulation for hydroxyl radical levels exhibited a clear hormesis-effect after exposure to soluble sulfide on LO2 cells (Figures 2-4) [62], which is consistent with a luminescent bacteria toxicity study, in which an opposite hormesis-effect appeared at the low concentrations of sulfide exposure [3]. These clear hormesis-effects provide further evidence of the protective ability of low-dose soluble sulfide and the 
toxicity of high-dose soluble sulfide, which should be considered by pharmaceutical researchers and public health research.

\section{Conclusions}

Soluble sulfide solutions at concentrations of $0.01-1.0 \mathrm{mM} / \mathrm{L}$ showed concentration-dependent cytotoxicity in the hepatocyte line LO2. While clear hormesis-effects were evident during the oxidative stress effect evaluation by the hydroxyl radical, the superoxide dismutase (SOD), and the glutathione peroxidase (GSH-Px) assays. The results indicate the protection of soluble sulfide at $0.01-0.1 \mathrm{mM} / \mathrm{L}$ against oxidative stress. Furthermore, the decrease in SOD and GSH-Px, in addition to the increase in hydroxyl radical by soluble sulphide suggests that oxidative damage could be a possible mechanism of cytotoxicity induced by sulphide in LO2 cells. However, further studies must analyze the different biological-level effects under oxidative stress conditions must be analyzed to demonstrate the protective role of soluble sulfide. The current study can serve as a step towards further demonstrating the mechanisms of soluble sulfide toxicity. These efforts provide the scientific underpinnings and regulatory reference for sulfide contaminations in the context of public and environmental health.

Author Contributions: Y.S. performed the majority of experiments and data evaluations and wrote the manuscript. Z.C. and L.W. supported the design of the experiments and the data evaluations, and Z.C. was a major contributor in writing the manuscript. All authors read and approved the final manuscript.

Funding: This research was funded by the Fundamental Research Funds for the Central Universities (No. 2019CDXYCH0026) and the Vebture \& Innovation Support Program for Chongqing Overseas Retureness (No. cx2018069).

Acknowledgments: We would like to thank Alphonse Habineza from School of Urban Construction and Environmental Engineering, Chongqing University, PR China for language editing of this manuscript.

Conflicts of Interest: The authors declare no conflict of interest.

\section{References}

1. Petruci, J.F.D.S.; Cardoso, A.A. A new palladium chelate compound for determination of sulfide. Microchem. J. 2013, 106, 368-372. [CrossRef]

2. Lin, H.W.; Lu, Y.; Ganigué, R.; Sharma, K.R.; Rabaey, K.; Yuan, Z.; Pikaar, I. Simultaneous use of caustic and oxygen for efficient sulfide control in sewers. Sci. Total Environ. 2017, 601-602, 776-783. [CrossRef]

3. Shao, Y.; Wu, L.L.; Gao, H.W.; Wang, F. Effect of Soluble Sulfide on the Activity of Luminescent Bacteria. Molecules 2012, 17, 6046-6055. [CrossRef] [PubMed]

4. Sonobe, T.; Haouzi, P. Sulfide Intoxication-Induced Circulatory Failure is Mediated by a Depression in Cardiac Contractility. Cardiovasc. Toxicol. 2016, 16, 67-78. [CrossRef]

5. Wang, R. Physiological implications of hydrogen sulfide: A whiff exploration that blossomed. Physiol. Rev. 2012, 92, 791-896. [CrossRef]

6. Sutherland-Stacey, L.; Corrie, S.; Neethling, A.; Johnson, I.; Gutierrez, O.; Dexter, R.; Yuan, Z.; Keller, J.; Hamilton, G. Continuous measurement of dissolved sulfide in sewer systems. Water Sci. Technol. 2008, 57, 375. [CrossRef] [PubMed]

7. Kimura, H. The physiological role of hydrogen sulfide and beyond. Nitric Oxide 2014, 41, 4-10. [CrossRef] [PubMed]

8. Aroca, A.; Gotor, C.; Romero, L.C. Hydrogen Sulfide Signaling in Plants: Emerging Roles of Protein Persulfidation. Front. Plant Sci. 2018, 9. [CrossRef] [PubMed]

9. Mustafa, A.K.; Gadalla, M.M.; Snyder, S.H. Signaling by gasotransmitters. Sci. Signal. 2009, 2, re2. [CrossRef]

10. Wang, R. Gasotransmitters: Growing pains and joys. Trends Biochem. Sci. 2014, 39, 227-232. [CrossRef]

11. Lefer, D.J. A new gaseous signaling molecule emerges: Cardioprotective role of hydrogen sulfide. Proc. Natl. Acad. Sci. USA 2007, 104, 17907-17908. [CrossRef] [PubMed]

12. European Science Foundation. European Network on Gasotransmitters; European Science Foundation: Strasbourg, France, 2011. 
13. Di Villa Bianca, R.D.E.; Sorrentino, R.; Maffia, P.; Mirone, V.; Imbimbo, C.; Fusco, F.; De Palma, R.; Ignarro, L.J.; Cirino, G. Hydrogen sulfide as a mediator of human corpus cavernosum smooth-muscle relaxation. Proc. Natl. Acad. Sci. USA 2009, 106, 4513-4518. [CrossRef]

14. Dominy, J.E.; Stipanuk, M.H. New roles for cysteine and transsulfuration enzymes: Production of H2S, a neuromodulator and smooth muscle relaxant. Nutr. Rev. 2010, 62, 348-353. [CrossRef] [PubMed]

15. Ahmad, F.U.D.; Sattar, M.A.; Rathore, H.A.; Abdullah, M.H.; Tan, S.; Abdullah, N.A.; Johns, E.J. Exogenous Hydrogen Sulfide (H2S) Reduces Blood Pressure and Prevents the Progression of Diabetic Nephropathy in Spontaneously Hypertensive Rats. Ren. Fail. 2012, 34, 203-210. [CrossRef] [PubMed]

16. Kamoun, P. H2S, a new neuromodulator. Med. Sci. 2004, 20, 697-700.

17. Yan, S.-K.; Chang, T.; Wang, H.; Wu, L.; Wang, R.; Meng, Q.H. Effects of hydrogen sulfide on homocysteine-induced oxidative stress in vascular smooth muscle cells. Biochem. Biophys. Res. Commun. 2006, 351, 485-491. [CrossRef]

18. Lan, A.; Liao, X.; Mo, L.; Yang, C.; Yang, Z.; Wang, X.; Hu, F.; Chen, P.; Feng, J.; Zheng, D. Hydrogen sulfide protects against chemical hypoxia-induced injury by inhibiting ROS-activated ERK1/2 and p38MAPK signaling pathways in PC12 cells. PLoS ONE 2011, 6, e25921. [CrossRef]

19. Wang, Y.L.; Jia, J.; Ao, G.Z.; Hu, L.F.; Liu, H.; Xiao, Y.Q.; Du, H.P.; Alkayed, N.J.; Liu, C.F.; Cheng, J. Hydrogen sulfide protects blood-brain barrier integrity following cerebral ischemia. J. Neurochem. 2014, 129, 827-838. [CrossRef] [PubMed]

20. Whiteman, M.; Armstrong, J.S.; Chu, S.H.; Jia-Ling, S.; Wong, B.S.; Cheung, N.S.; Halliwell, B.; Moore, P.K. The novel neuromodulator hydrogen sulfide: An endogenous peroxynitrite 'scavenger'? J. Neurochem. 2004, 90, 765-768. [CrossRef] [PubMed]

21. Whiteman, M.; Cheung, N.S.; Zhu, Y.-Z.; Chu, S.H.; Siau, J.L.; Wong, B.S.; Armstrong, J.S.; Moore, P.K. Hydrogen sulphide: A novel inhibitor of hypochlorous acid-mediated oxidative damage in the brain? Biochem. Biophys. Res. Commun. 2005, 326, 794-798. [CrossRef] [PubMed]

22. Yan, X.J.; Zhang, L.; Guo, J.M.; Cao, Y.D.; Shang, E.S.; Tang, Y.P.; Ding, A.W.; Duan, J.A. Processing of kansui roots stir-baked with vinegar reduces kansui-induced hepatocyte cytotoxicity by decreasing the contents of toxic terpenoids and regulating the cell apoptosis pathway. Molecules 2014, 19, 7237-7254. [CrossRef]

23. Wu, L.; Ying, S.; Hu, Z.; Gao, H. Effects of soluble sulfide on zebrafish (Danio rerio) embryonic development. Environ. Toxicol. Pharm. 2016, 42, 183-189. [CrossRef]

24. Patravale, V.; Dandekar, P.; Jain, R. Nanotoxicology: Evaluating toxicity potential of drug-nanoparticles. Nanopart. Drug Deliv. 2012, 64, 123-155.

25. Riss, T.L.; Moravec, R.A.; Niles, A.L.; Benink, H.A.; Worzella, T.J.; Minor, L. Cell Viability Assays-Assay Guidance Manual; Company and the National Center for Advancing Translational Sciences: Bethesda, MD, USA, 2004.

26. Hayyan, M.; Hashim, M.A.; Alnashef, I.M. Superoxide Ion: Generation and Chemical Implications. Chem. Rev. 2017, 116, 3029-3085. [CrossRef]

27. Luo, J.; Nikolaev, A.Y.; Imai, S.; Chen, D.; Su, F.; Shiloh, A.; Guarente, L.; Gu, W. Negative Control of p53 by Sir2 $\alpha$ Promotes Cell Survival under Stress. Cell 2001, 107, 137-148. [CrossRef]

28. Yu, Q.; Lu, Z.; Tao, L.; Yang, L.; Guo, Y.; Yang, Y.; Sun, X.; Ding, Q. ROS-Dependent Neuroprotective Effects of NaHS in Ischemia Brain Injury Involves the PARP/AIF Pathway. Cell. Physiol. Biochem. 2015, 36, 1539-1551. [CrossRef] [PubMed]

29. Yang, B.; Xu, Y.; Hu, Y.; Luo, Y.; Lu, X.; Tsui, C.K.; Lu, L.; Liang, X. Madecassic Acid protects against hypoxia-induced oxidative stress in retinal microvascular endothelial cells via ROS-mediated endoplasmic reticulum stress. Biomed. Pharmacother. 2016, 84, 845-852. [CrossRef]

30. Tang, J.; Lei, C.; Qiang, L.; Wang, L.; Gang, J.; Liu, G.; Chen, X.; Cai, J.; Shang, H.; Hua, Z. Selenoprotein $X$ Gene Knockdown Aggravated $\mathrm{H}_{2} \mathrm{O}_{2}$-Induced Apoptosis in Liver $\mathrm{LO}_{2}$ Cells. Biol. Trace Elem. Res. 2016, 173, 1-8. [CrossRef] [PubMed]

31. Storch, A.; Burkhardt, K.; Ludolph, A.C.; Schwarz, J. Protective effects of riluzole on dopamine neurons: Involvement of oxidative stress and cellular energy metabolism. J. Neurochem. 2000, 75, 2259-2269. [CrossRef] [PubMed]

32. Szabo, A.; Balog, M.; Mark, L.; Montsko, G.; Turi, Z.; Jr, F.G.; Sumegi, B.; Kalai, T.; Hideg, K.; Kovacs, K. Induction of mitochondrial destabilization and necrotic cell death by apolar mitochondria-directed SOD mimetics. Mitochondrion 2011, 11, 476-487. [CrossRef] [PubMed] 
33. Fubini, B.; Hubbard, A. Reactive oxygen species (ROS) and reactive nitrogen species (RNS) generation by silica in inflammation and fibrosis. Free Radic. Biol. Med. 2003, 34, 1507-1516. [CrossRef]

34. Woolliams, J.; Wiener, G.; Anderson, P.; McMurray, C. Variation in the activities of glutathione peroxidase and superoxide dismutase and in the concentration of copper in the blood in various breed crosses of sheep. Res. Vet. Sci. 1983, 34, 253. [CrossRef]

35. Lin, M.T.; M Flint, B. Mitochondrial dysfunction and oxidative stress in neurodegenerative diseases. Nature 2006, 443, 787-795. [CrossRef] [PubMed]

36. Paglia, D.E.; Valentine, W.N. Studies on the quantitative and qualitative characterization of erythrocyte glutathione peroxidase. J. Lab. Clin. Med. 1967, 70, 158.

37. Ortega, J.; Ortega, J.; Julian, D. Hypotaurine and sulfhydryl-containing antioxidants reduce H2S toxicity in erythrocytes from a marine invertebrate. J. Exp. Biol. 2008, 211, 3816-3825. [CrossRef]

38. Beauchamp, R.; Bus, J.S.; Popp, J.A.; Boreiko, C.J.; Andjelkovich, D.A.; Leber, P. A critical review of the literature on hydrogen sulfide toxicity. CRC Crit. Rev. Toxicol. 1984, 13, 25-97. [CrossRef] [PubMed]

39. Cooper, C.E.; Brown, G.C. The inhibition of mitochondrial cytochrome oxidase by the gases carbon monoxide, nitric oxide, hydrogen cyanide and hydrogen sulfide: Chemical mechanism and physiological significance. J. Bioenergy Biomembr. 2008, 40, 533-539. [CrossRef]

40. Eghbal, M.A.; Pennefather, P.S.; O’Brien, P.J. $\mathrm{H}_{2} \mathrm{~S}$ cytotoxicity mechanism involves reactive oxygen species formation and mitochondrial depolarisation. Toxicology 2004, 203, 69-76. [CrossRef]

41. Truong, D.H.; Eghbal, M.A.; Hindmarsh, W.; Roth, S.H.; O’Brien, P.J. Molecular Mechanisms of Hydrogen Sulfide Toxicity. Drug Metab. Rev. 2006, 38, 733-744. [CrossRef]

42. Kombian, S.B.; Reiffenstein, R.; Colmers, W.F. The actions of hydrogen sulfide on dorsal raphe serotonergic neurons in vitro. J. Neurophysiol. 1993, 70, 81-96. [CrossRef]

43. Ahlman, K.; Koskela, R.S.; Kuikka, P.; Koponen, M.; Annanmaki, M. Mortality among sulfide ore miners. Am. J. Ind. Med. 1991, 19, 603-617. [CrossRef] [PubMed]

44. Turrens, J.F. Mitochondrial formation of reactive oxygen species. J. Physiol. 2003, 552, 335-344. [CrossRef] [PubMed]

45. Cabiscol, E.; Tamarit, J.; Ros, J. Oxidative stress in bacteria and protein damage by reactive oxygen species. Int. Microbiol. 2010, 3, 3-8.

46. Buonocore, G.; Perrone, S.; Tataranno, M.L. Oxygen toxicity: Chemistry and biology of reactive oxygen species. Semin. Fetal Neonatal Med. 2010, 15, 186-190. [CrossRef] [PubMed]

47. Nordberg, J.; Arner, E.S. Reactive oxygen species, antioxidants, and the mammalian thioredoxin system. Free Radic. Biol. Med. 2001, 31, 1287-1312. [CrossRef]

48. Sun, Y.; Yin, Y.; Zhang, J.; Yu, H.; Wang, X.; Wu, J.; Xue, Y. Hydroxyl radical generation and oxidative stress in Carassius auratus liver, exposed to pyrene. Ecotoxicol. Environ. Saf. 2008, 71, 446-453. [CrossRef] [PubMed]

49. Wu, Z.F.; Yan, Z.; Zhao, B.L. Superoxide anion, uncoupling proteins and Alzheimer's disease. J. Clin. Biochem. Nutr. 2010, 46, 187-194. [CrossRef]

50. Sun, W.H.; Liu, F.; Chen, Y.; Zhu, Y.C. Hydrogen sulfide decreases the levels of ROS by inhibiting mitochondrial complex IV and increasing SOD activities in cardiomyocytes under ischemia/reperfusion. Biochem. Biophys. Res. Commun. 2012, 421, 164-169. [CrossRef]

51. Olson, K.R.; Gao, Y.; Arif, F.; Arora, K.; Patel, S.; Deleon, E.; Sutton, T.R.; Feelisch, M.; Cortese-Krott, M.M.; Straub, K.D. Metabolism of Hydrogen Sulfide $\left(\mathrm{H}_{2} \mathrm{~S}\right)$ and Production of Reactive Sulfur Species (RSS) by Superoxide Dismutase. Redox Biol. 2018, 15, 74-85. [CrossRef]

52. Birben, E.; Sahiner, U.M.; Sackesen, C.; Erzurum, S.; Kalayci, O. Oxidative Stress and Antioxidant Defense. World Allergy Organ. 2012, 5, 9-19. [CrossRef]

53. La Russa, D.; Brunelli, E.; Pellegrino, D. Oxidative imbalance and kidney damage in spontaneously hypertensive rats: Activation of extrinsic apoptotic pathways. Clin. Sci. 2017, 131, 1419-1428. [CrossRef] [PubMed]

54. Simic, T.; Savic-Radojevic, A.; Pljesa-Ercegovac, M.; Matic, M.; Mimic-Oka, J. Glutathione S-transferases in kidney and urinary bladder tumors. Nat. Rev. Urol. 2009, 6, 281-289. [CrossRef] [PubMed]

55. Whitson, J.A.; Wilmarth, P.A.; Klimek, J.; Monnier, V.M.; David, L.; Fan, X. Proteomic analysis of the glutathione-deficient LEGSKO mouse lens reveals activation of EMT signaling, loss of lens specific markers, and changes in stress response proteins. Free Radic. Biol. Med. 2017, 113, 84-96. [CrossRef] 
56. Wu, D.; Hu, Q.; Liu, X.; Pan, L.; Xiong, Q.; Zhu, Y.Z. Hydrogen sulfide protects against apoptosis under oxidative stress through SIRT1 pathway in H9c2 cardiomyocytes. Nitric Oxide 2015, 46, 204-212. [CrossRef] [PubMed]

57. Blum, J.; Fridovich, I. Inactivation of glutathione peroxidase by superoxide radical. Arch. Biochem. Biophys. 1985, 240, 500-508. [CrossRef]

58. Gansukh, E.; Mya, K.K.; Jung, M.; Keum, Y.-S.; Kim, D.H.; Saini, R.K. Lutein derived from marigold (Tagetes erecta) petals triggers ROS generation and activates Bax and caspase-3 mediated apoptosis of human cervical carcinoma (HeLa) cells. Food Chem. Toxicol. 2019, 127, 11-18. [CrossRef]

59. Shimada, S.; Fukai, M.; Wakayama, K.; Ishikawa, T.; Kobayashi, N.; Kimura, T.; Yamashita, K.; Kamiyama, T.; Shimamura, T.; Taketomi, A.; et al. Hydrogen sulfide augments survival signals in warm ischemia and reperfusion of the mouse liver. Surg. Today 2015, 45, 892-903. [CrossRef]

60. Iwayama, K.; Kimura, J.; Mishima, A.; Kusakabe, A.; Ohtaki, K.; Tampo, Y.; Hayase, N. Low concentrations of clarithromycin upregulate cellular antioxidant enzymes and phosphorylation of extracellular signal-regulated kinase in human small airway epithelial cells. J. Pharm. Health Care Sci. 2018, 4, 14. [CrossRef] [PubMed]

61. Wang, Y.; Li, Y.; Yang, Z.P.; Wang, Z.Q.; Chang, J.; Zhang, T.; Chi, Y.Q.; Han, N.; Zhao, K.X. Pyridoxamine Treatment of HK-2 Human Proximal Tubular Epithelial Cells Reduces Oxidative Stress and the Inhibition of Autophagy induced by High Glucose Levels. Med. Sci. Monit. 2019, 25, 1480-1488. [CrossRef]

62. Jiao, Z.H.; Li, M.; Feng, Y.X.; Shi, J.C.; Zhang, J.; Shao, B. Hormesis Effects of Silver Nanoparticles at Non-Cytotoxic Doses to Human Hepatoma Cells. PLoS ONE 2014, 9, e102564. [CrossRef]

(C) 2019 by the authors. Licensee MDPI, Basel, Switzerland. This article is an open access article distributed under the terms and conditions of the Creative Commons Attribution (CC BY) license (http://creativecommons.org/licenses/by/4.0/). 